\title{
NOTABLE ATTRIBUTES OF INDIA INNOVATIVE MANAGEMENT
}

\author{
Pavel Šenkýŕr ${ }^{1}$ \\ ${ }^{1}$ W2W s.r.o., Rybkova 23, 60200 Brno \\ Email: polo@calypsa.cz
}

\begin{abstract}
This article consists of choosen results of personal knowledge, published interviews, press, monographies, conference, literature and questionnaire researches. There were analyzed information out of the 154 Indian company executives, employees or company trainees, operating directly in India or in Indian managed companies abroad, about their methods for recruiting talented and, to company goals oriented, loyal team. The arguments of this research are mainly the facts that over the last two decades, many of India's leading companies have been achieving double digit growth - even in the situation of global recession. Some of the biggest and most traditional iconas of the European or US industry, such as Volvo, Land Rover, Jaguar, or lots of smaller companies had to be sold. Who were - and still are - the buyers? Indians. Thus, understanding what is leading the Indian business leaders is an imperative that no manager can afford to ignore. The Partial research reasons should inspire other managers, briefly show common marks and explain how these Indian innovations work within Indian companies, identifying those marks and methods to remove and those that can be adapted to the Western context.
\end{abstract}

Keywords: company vision, flexibility, governance, holistic engagement, leadership, organisational architecture, process.

JEL classification: D21, D22

Doručeno redakci: 29.6.2011; Recenzováno: 11.2.2013; 3.4.2013; Schváleno k publikování: 11.9.2013

\section{Introduction}

India Lonely planet guidebook issued in 1992 says: "The only thing, that Indians accomplished to improve in their times of independence from 1947, is the bureaucracy". The first picture of India and its economy situation till 1990 was dust and streets mostly covered with burning, putrefying and stinking rubbish.

The contrasts between wealth and poverty were extreme - luxury buildings rose amid squalid slums and dying people on the streets of Old Delhi, together with speeding luxury airconditioned cars narrowly missed homeless sleeping along the roads. Until the collaps of the Soviet Union, long term, large and reliable trading partner of India, India's GDP had grown at annual rates of just 2-3\%, but in real per capita terms, the growth was close to zero, since the population had been expanding at a comparable pace. The turning point came in 1991 with the massive reduction of the state role. 1990s and 2000s witnessed major changes in the Indian economy due to economic liberalization in India. This revitalization took place in the whip of balance-of-payment emergency - Cappelli (2010). The government of India allowed private infusions in Indian market which facilitated monetary infusion from FDI and FII. Information technology, telecommunications, electronics and hardware, pharmaceuticals, biotechnology, consumer durables, retail, infrastructure, airlines, hospitality, power, etc. are sectors which contributed to the success of India GDP history post 1990s - Fig. 1. - Fig. 3. 
Figure 1: GDP growth 1990 - 2009 [\%]

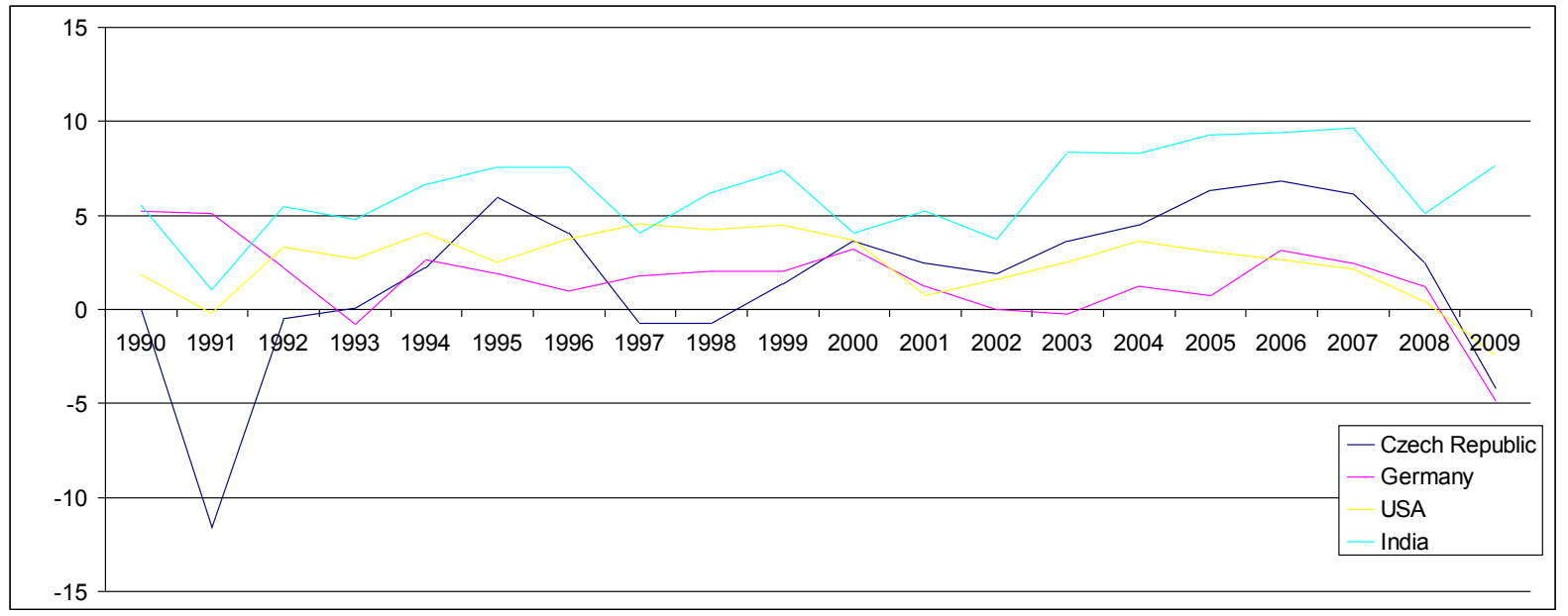

Source: author. Data source : Web portal of Worldbank. 〈http://www.worldbank.com>

Figure 2: GDP per capita growth 1990 - 2009 [\%]

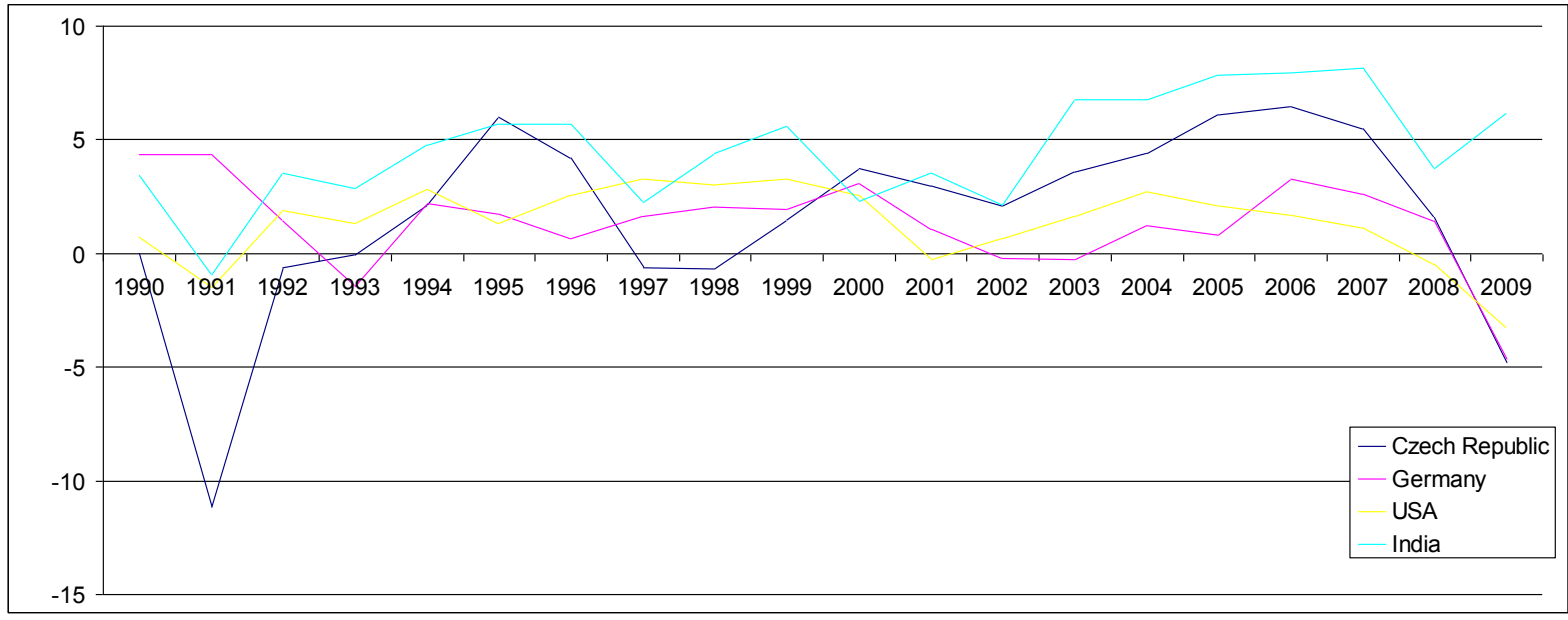

Source: author. Data source : Web portal of Worldbank. 〈http://www.worldbank.com>

Figure 3: Indian company trasnational mergers and acquisitions, 1990 - 2009 [mill. of USD]

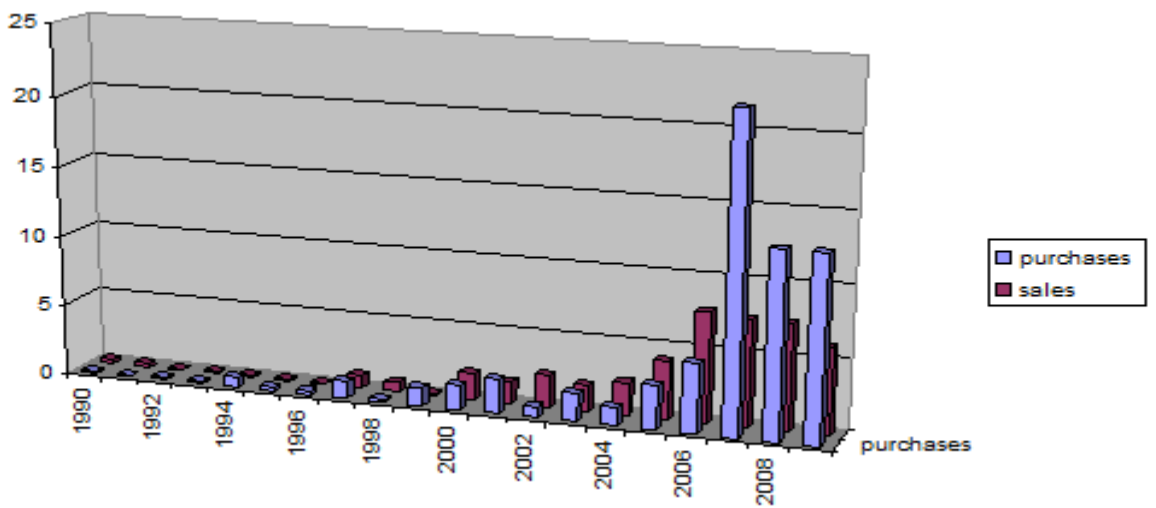

Source: Euromonitor international, May 2010

Bureaucracy still seems to be endemic in India's political and economic life, but over the last 20 years, many of India's leading companies have been achieving double digit growth - even surrounded by global recession. Some of the biggest and most traditional icons of the 
European or US industry, such as Volvo, Land Rover, Jaguar, or lots of smaller companies had to be sold. Who were - and still are - the buyers? Indians. Thus, understanding what is driving the Indian business leaders is an imperative that no manager can afford to ignore. The Asian - specially Indian management style consists of unique mix of organizational capabilities, unique managerial practices, and distinctive aspects of company cultures that sets Indian enterprises apart from firms in other countries - Cappelli (2010). The objectives of this paper should be a partial inspiration of the other managers, briefly showing common marks and explaining how these Indian innovations work within Indian companies, identifying those marks and methods to remove and those that can be adapted to the Western context.

\section{Methods and sources}

Survey area of this research is the economic and especially managerial space of Indian managed companies. General question of the survey is: "What are the main managerial attributes and partially the reasons of the Indian economy growth."

The main hypothesis is: "The main reason of Indian economy success is the massive company rise caused by its company management." That is why the survey is focused on the management and not on finance and business economy because in the global economy space, the common general rights of the company / economy growth and of the company financial governance are not impugnable and are the same in India, Australia, USA, Germany or Greece (but not kept everywhere). This hypothesis is also supported by Hamel's [3] statement: "The main factor influencing the company power and ability is not a financial or business model, but its governance-managerial model."

Partial questions of the survey were:

1. What are the main attributes of Indian leadership ?

2. What are the top priorities for Indian HR managers ?

3. What are the top priorities for Indian human resources in the company?

4. What are the more distinctive aspects of Indian corporate governance practices ?

Time interval of the research was March 2006 - March 2011.

Survey methods and its relative representation in the survey:

1. Interview $(23 \%)$

2. MLQ questionnaire (25\%). To examine the Idian leader's style modified Multifactor Leadership Questionnaire (MLQ) was used - the most widely used assessment of leadeship in USA. ${ }^{1}$ The modification subsisted in simplification.

3. Analyses and literary research of economical texts, monographies and interviews $(52 \%)$

Information sources:

The base of the information sources consists of 154 CEOs, stockholders, top, middle and line managers, employees and trainees working for 60 Indian managed companies directly in India or abroad. The structure of information source base shows Tab. I. - Tab. III.

\footnotetext{
${ }^{1}$ www.mindgarden.com
} 
Table 1: Information base - industry sector structure

\begin{tabular}{|l|c|}
\hline Industry sector & percentage \\
\hline Information technology & 11 \\
\hline Pharmaceuticals and biotechnology & 8,3 \\
\hline Travel business and hotels & 5,1 \\
\hline Oil and gas & 8 \\
\hline Steel & 4 \\
\hline Beverages and food & 2 \\
\hline Shipping & 6 \\
\hline Glass & 1 \\
\hline Agriculture & 3,4 \\
\hline Chemicals and plastic materials & 6,2 \\
\hline Health care & 4 \\
\hline Mining & 4 \\
\hline Wehicles and trucks, Automobiles and autoparts & 6 \\
\hline Telecomunications & 5 \\
\hline Education & 3 \\
\hline Finance & 6 \\
\hline Transportation & 5 \\
\hline Leather and textile & 5 \\
\hline Building industries and materials & 7 \\
\hline
\end{tabular}

Source: author

Table 2: Information base - company multinationality structure Multinational company

yes

no

Source: author 
Table 3: Information base - characteristics of surveyed subjects

\begin{tabular}{|c|c|c|}
\hline Age in years & Category & percentage \\
\hline & $20-30$ & 1,5 \\
\hline & $31-40$ & 3 \\
\hline & $41-50$ & 16 \\
\hline & $50-59$ & 52 \\
\hline & $60-69$ & 20 \\
\hline & $70+$ & 2,5 \\
\hline & No age information given & 5 \\
\hline \multirow[t]{3}{*}{ Gender } & Category & percentage \\
\hline & Male & 97,2 \\
\hline & Female & 2,8 \\
\hline \multirow[t]{5}{*}{ Education lev. } & Category & percentage \\
\hline & Non degree & 35 \\
\hline & Bachelor & 58 \\
\hline & Master / Engineer & 4,7 \\
\hline & Doctorate and higher & 2,3 \\
\hline \multirow[t]{9}{*}{ Study spec. } & \begin{tabular}{|l|} 
Category \\
\end{tabular} & percentage \\
\hline & Business & 19 \\
\hline & Engineering & 17 \\
\hline & Natural science & 10 \\
\hline & Agriculture & 25 \\
\hline & Law & 5 \\
\hline & Medicine & 5 \\
\hline & Social sciences, arts & 33 \\
\hline & None & 5 \\
\hline \multirow[t]{7}{*}{ Company stat. } & Category & percentage \\
\hline & Owner & 7 \\
\hline & Executive & 11 \\
\hline & Top management & 18 \\
\hline & Mid. and operational management & 23 \\
\hline & Leading employee without higher status & 29 \\
\hline & Trainee on leadin position & 12 \\
\hline
\end{tabular}

Source: author

\section{Results}

Results of the survey are divided into three parts: 1. Leadership and HR managemnt, 2. Governance, and 3. Sources of competitive advantage:

\subsection{Leadership and HR management}

Indian leaders mostly (33\%) characterize their leadership style as "transformation style" often called as "charismatic leadership". This access is conditioned by leader's personal participation in main projects and processes. Less used leadership styles are transactional $(19 \%)$ and partnership (18\%) - Fig. 4. The rest of leadership style types is minor and presents from $3 \%$ to $9 \%$. 
Figure 4: Leadership styles of India leaders

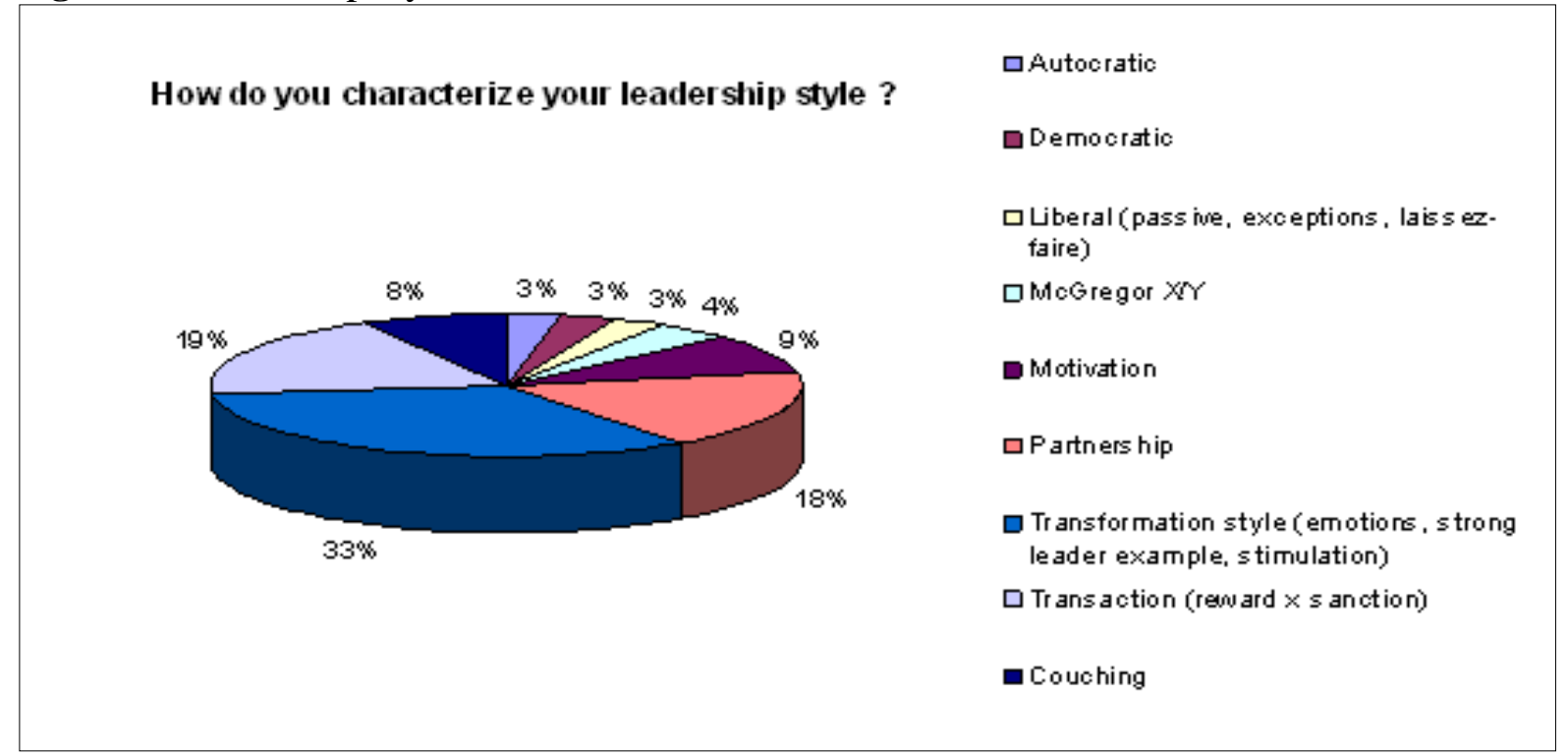

Source: author

The part of research aimed on critical leadership capacities - Fig. 5, shows that mostly and best evaluated capacity is visioning together with strategic thinking, ability to create optimal organisational structure and human working environment. Flexibility in place and time, together with willingness to risk is not spread and evaluated as wide as in relative more rival western leader community.

Figure 5: Critical leadership capacities of Indian leaders

What are your 3 critic al leadership capacities?

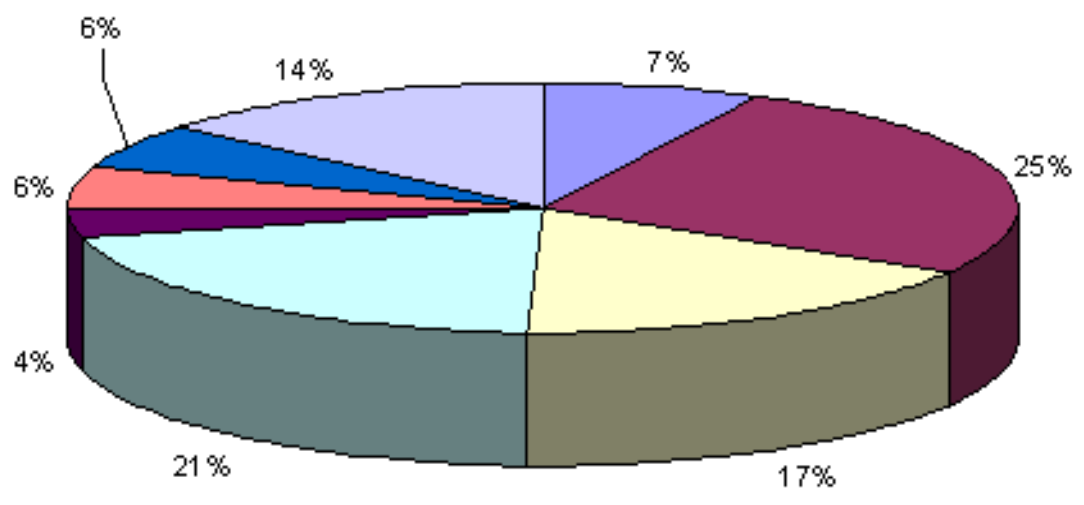

$\square$ willingness to risk

Q visioning capacities i strategic thinking

$\square$ architecture and organizational cap.

$\square$ inspiration, human access and teaching

$\square$ flexbility in time and place

talent

market, supplier and competitor relations

$\square$ professional experience

Source: author 
Figure 6: Top three critical leadership roles of Indian leaders

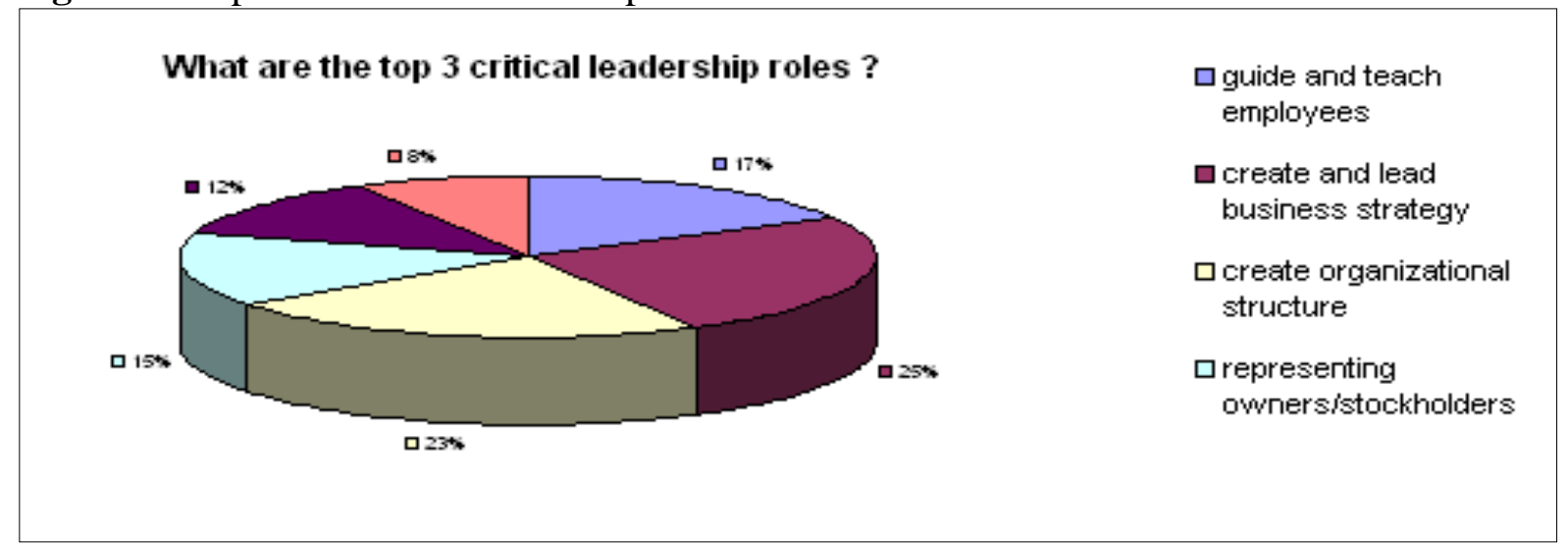

Source: author

The difference of Western concept is significant. Chief executives usually keep effort of maximising shareholder value as their most important priority. Shareholders for Indian executives are down the priority list - bellow the customers, employees and broad society. This "pulling effect" finally turns into the company growth and stockholders profit - Fig. 6.

\subsection{Governance}

The governance board of the Western held companies is traditionally represented as the owner's eyes, ears and fingers - Cappelli (2010). The conventional model of corporate governance is well known for its simplicity - stockholders elect company directors according to the right "one share - one vote". The failures of Enron etc. in 2002 was mainly attributed to the failure of their directors even monitoring their managers. Many countries, including India, have been forced by this influence to set new rules for governing companies. The Indian Securities and Exchange board - commonly known as SEBI, proclaimed a new set of rules in 2004, known as "rubric - clause 49". Among of the most important attributes of this rule belongs to the regulation settings that the number of independent nonexecutive directors must constitute at least half of the board. The argument for this rule is obvious: independent nonexecutive directors would strengthen the monitoring of managers. Using of one executive manager seems to be one of the important attributes of India success. The outline of executive criteria for choosing nonexecutive directors shows Fig. 7.

Figure 7: Executives criteria for nonexecutive directors

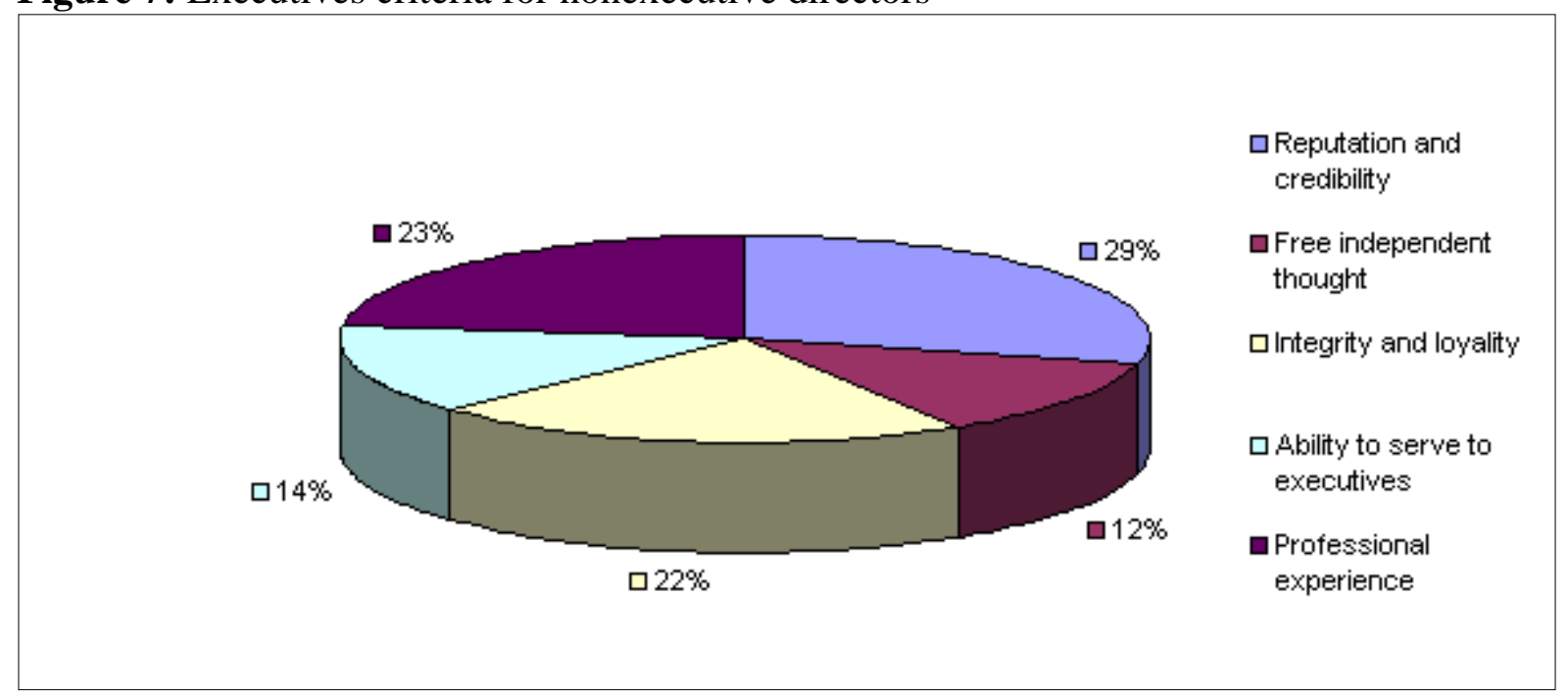

Source: author 


\subsection{Sources of competitive advantages}

Indian leaders indicates the focus on customer as the main (16\%) source of competitive advantage that is not a "revolutionary assignment" in market oriented economy. But actually the same meaning $(17 \%)$ has the strong and effective working team - Fig. 8. Employee team and employer itself is not only the production factor (in contrast with the Western system) to be optimized and treated in the form of personal number. Every employee is a Part of the Project and it is hard to find the better term for the form of this symbiosis then Cappelli (2010) use - "holistic" - Fig. 8. and Fig. 9.

Figure 8: Three most important sources of competitive advantage

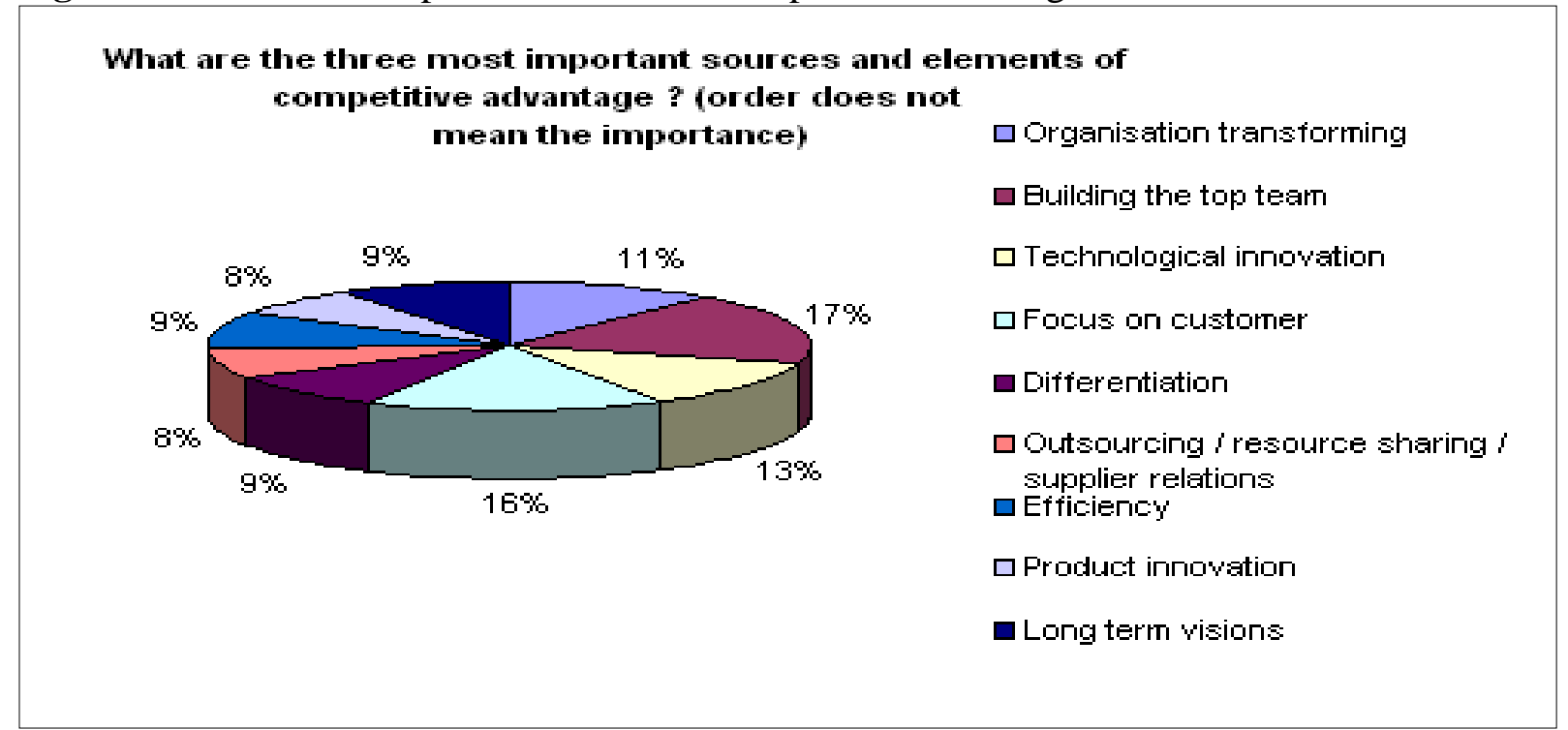

Source: author

Figure 9: Empolyee / subsidiaries process orientation

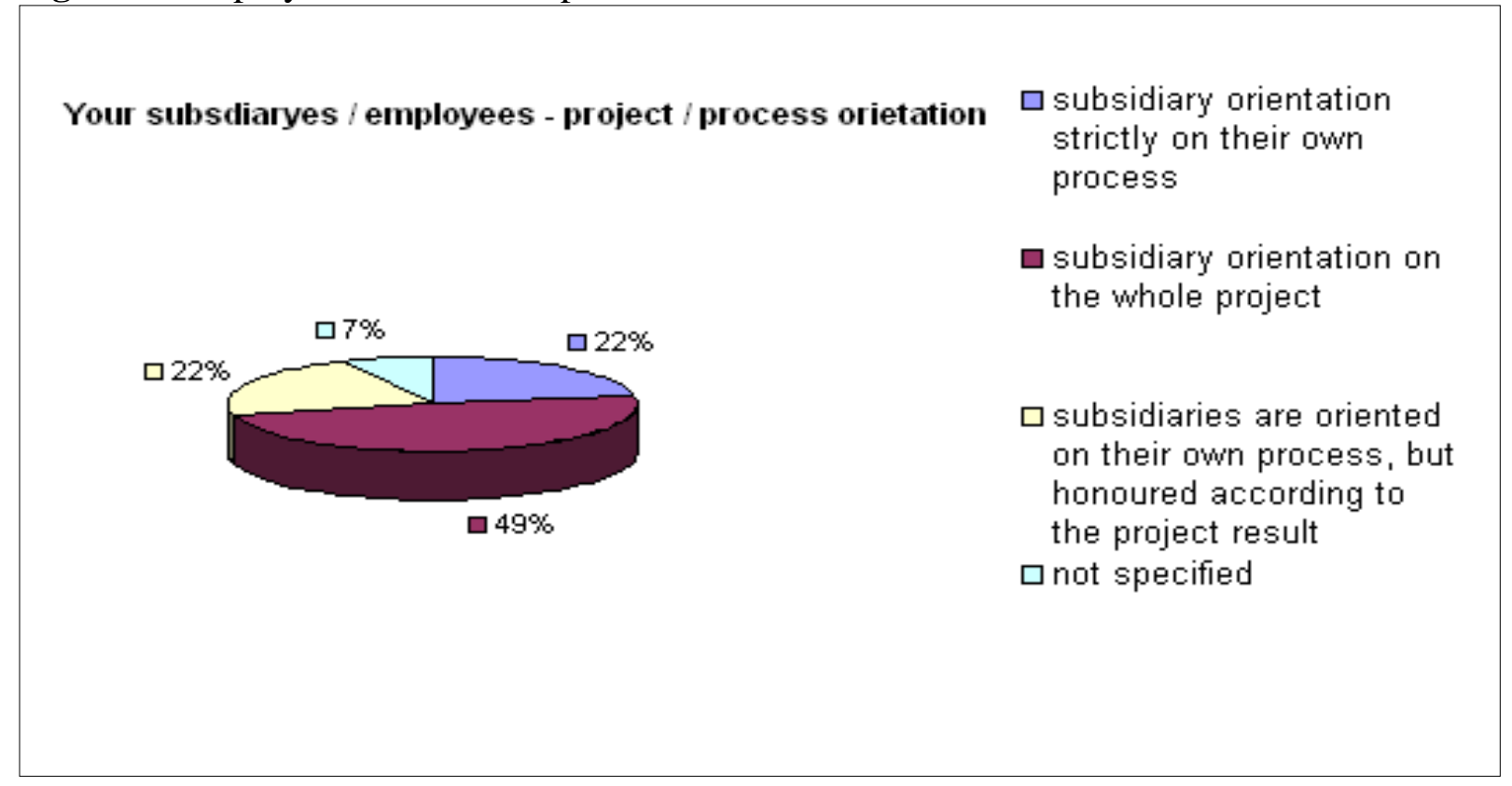

Source: author 


\section{Conclusion}

Results of this paper confirms Cappelli`s - 2010 statements. Main principal practices of India innovative management are: Extremely high (Indian) improvisation and adaptability, Global holistic engagement with employees, Creative value propositions and Wide (Broad) mission and purpose. Team power and employee cooperation purpose is more important than the interests of stockholders.

Global engagement with employees - Indian business leaders treat their firms as organic body system, where employee morale and gaining company culture are treated as critical attributes of their success. People are viewed as assets to be developed, not cost to be reduced and optimized as a production factor. Creating ever-stronger capabilities in the workforce is a driving objective.

Improvisation and adaptability - Improvisation is the "synonymum of India". Things like Bajaj riksha, Bombaj and Calcutta subway or Bolliwood films prove it. In a often volatile environment, business leaders have learned to remain on their goals. Adaptability is crucial as well, and it is also frequently referenced in an English-Hindi hybrid word "adjust kar lenge" "we will adjust".

Broad mission and purpose - Indian business leaders place special emphasis on personal values, a vision of growth, and strategic thinking. The leaders are very proud of enterprise success - but also of family prosperity, regional advancement, and national renaissance.

The main result should be the fact, that mentioned principles are not as unique, so they can work only in India. One of main attributes is the researched facts that good employee and team are most important source of company power, together with the fact that Indian executives are more respectful of seniority, government and tradition. They often rely more upon their intuition than their Western counterparts.

\section{References}

[1] CAPPELli, P., H. SINGH, J. SINGH and M. USEE, 2010: The India Way. $1^{\text {st }}$. edition. Boston: Harward Business Press, 332 p. ISBN 978-1-4221-4759-7.

[2] HAMEL, G. and B. BREEN, 2008: The Future of management. $1^{\text {st }}$. edition. Boston: Harward Business Press, 245 p. ISBN 978-80-7261-188-1.

[3] WREN, D. A. and A. G. BEDEIAN, 2010: The evolution of management thought. $6^{\text {th. }}$ edition. Hoboken (MA): John Wiley and sons, 532 p. ISBN 13:978-0-47012897-8. 